\title{
Genetics of the FANCA gene in familial pancreatic cancer
}

\author{
C D Rogers, F J Couch, K Brune, S T Martin, J Philips, K M Murphy, G Petersen, C J Yeo, \\ R H Hruban, M Goggins
}

J Med Genet 2004;41:e126 (http://www.jmedgenet.com/cgi/content/full/41/12/e126). doi: 10.1136/jmg.2004.024851

$\mathrm{F}$ anconi anaemia (FA) is a rare autosomal recessive disease that is characterised by bone marrow failure, pancytopenia, and an increased susceptibility to cancers. Recently, D'Andrea and coworkers identified biallelic BRCA2 gene mutations as a cause of FA. ${ }^{1}$ Because of the role of BRCA2 gene mutations in pancreatic cancer development, their findings suggested other members of the FA pathway may be targeted for genetic inactivation in pancreatic cancer. Indeed, somatic and inherited mutations of FANCC and somatic mutations in FANCG were subsequently identified in patients with apparently sporadic pancreatic cancer. ${ }^{2}$ These data led to analysis of the FANCC and FANCG genes in the germline of families with multiple pancreatic cancers, but no mutations were identified. ${ }^{3}$ In most populations, FANCA is the most commonly mutated gene in patients with FA. ${ }^{4-14}$ In this study we determined if FANCA gene mutations predispose to the development of familial pancreatic cancer.

\section{METHODS \\ Subjects}

Lymphocyte DNA was analysed from patients with familial pancreatic cancer enrolled in the National Familial Pancreatic Tumor Registry. ${ }^{15}$ Patients with pancreatic cancer were selected if they had at least two or more first degree relatives with pancreatic cancer (mean (SD) age of 66.7 (12.3) years, males 50.3\%). Variants were analysed in 110 additional patients with familial pancreatic cancer. To determine the carrier frequency of c.2574C >G (p.Ser868Arg), we analysed three control populations: healthy spouses of patients with familial pancreatic cancer ( 115 samples from spouses with a mean (SD) age of 66.9 (11.3) years, males $43.1 \%$ ), patients who had undergone cholecystectomy (65 samples matched in age with sporadic cases) for non-malignant disease at Johns Hopkins Hospital, and individuals undergoing routine screening colonoscopy (668 samples) at the Mayo Clinic. The mean age of the colonoscopy controls was similar to our pancreatic cancer population (mean (SD) age of 59.3 (12.3) years, males $52.9 \%$ ).

Lymphocyte DNA was obtained from spousal controls and colonoscopy controls, and formalin fixed paraffin embedded DNA from the resected gallbladders of hospital controls. None of the controls had a prior history of pancreatic cancer or colorectal cancer. We also analysed germline DNA from 124 individuals with apparently sporadic pancreatic cancer (those without a known family history of pancreatic cancer; mean (SD) age of 66.23 (10.3) years, males $48 \%$ ). This study was approved by the Johns Hopkins Joint Committee for Clinical Investigation and the Mayo Clinic IRB.

\section{FANCA analysis}

FANCA (Genbank \# NM_000135.1) was analysed using a combination of heteroduplex analysis and DNA sequencing. A detailed description of methods used including primer sequences can be accessed at http://www.pathology2.jhu. edu/pancreas/FANCA and at http://jmg.bmjjournals.com/ supplemental/. The Fanconi Anemia Mutation Database

\section{Key points}

- FANCA was examined as a candidate susceptibility gene for familial pancreatic cancer by using heteroduplex analysis and sequencing of lymphocyte DNA from 44 patients with familial pancreatic cancer.

- Several exonic variants were identified including two novel, c.377C $>$ G (p.Thr126Arg) and c.661A>G (p.Met221 Val), and one disease associated variant, c. $2574 \mathrm{C}>\mathrm{G}$ (p.Ser858Arg).

- The prevalence of the c. $2574 C>G$ variant in additional familial pancreatic cancer cases was similar to that of control individuals without cancer.

- Despite finding a disease associated variant in multiple individuals with familial pancreatic cancer, our results suggest that germline FANCA gene mutations do not contribute to familial pancreatic cancer susceptibility.

at http://www.rockefeller.edu/fanconi/mutate/jumpa.html was used to identify previously documented variants and their frequencies. Nucleotide position $+\mathrm{l}$ corresponds to the $\mathrm{A}$ of the ATG translation initiation codon 1 (methionine).

\section{RESULTS AND DISCUSSION}

A total of 43 exons were examined in 44 DNA samples by heteroduplex analysis (1892 PCR products). A total of 375/ 1892 PCR products had heteroduplex alterations and sequence alterations were found in 342 of the 375 exons with PCR heteroduplexes. The 392 alleles tested shared 48 different FANCA sequence variations. These included 12 exonic variants (table 1 ) and 36 intronic variants (table 2 ). Of the 48 variants found, one is an intronic insertion, another is an intronic deletion, and the rest were single base pair changes, the majority of which were transitions.

The FA associated variant c.2574C $>$ G (S858R), first documented by Wijker et al, ${ }^{16}$ was identified in two patients (Pl and P2) with familial pancreatic cancer. The primary cancer from these patients was not available, but germline DNA was available from only one family member from the same kindred as $\mathrm{Pl}$ who was also diagnosed with pancreatic cancer. This individual, the father of $\mathrm{Pl}$, was diagnosed at age 80 and developed pancreatic cancer much later than his son (age 49). The father of Pl did not harbour the c.2574C $>\mathrm{G}$ variant.

In an additional 110 patients with familial pancreatic cancer, three contained c.2574C $>$ G. In all, five of 154 familial samples contained c. $2574 \mathrm{C}>\mathrm{G}$ (odds ratio (OR) 1.530, 95\% confidence interval (CI) 0.560 to 4.181 ). The c.2574C $>\mathrm{G}$ variant was also seen in one of 124 patients with sporadic pancreatic cancer (OR $0.380,95 \%$ CI 0.050 to 2.87), in 0 of 65

Abbreviations: FA, Fanconi anaemia 
Table 1 Exonic FANCA sequence variants in pancreatic cancer

\begin{tabular}{|c|c|c|c|c|c|c|}
\hline Exon & Nucleotide change & Familial† & Sporadics $\ddagger$ & Controls & Amino acid change & FA database $\S$ \\
\hline 4 & c. $377 C>G$ & $1 / 44(G)$ & ND & $0 / 115$ & p.Thr126Arg & $\mathrm{N}$ \\
\hline 7 & c. $661 A>G$ & $1 / 44(G)$ & ND & $0 / 115$ & p.Met221 Val & $\mathrm{N}$ \\
\hline 13 & c. $1143 G>T$ & $6 / 44(T)$ & ND & ND & None & $Y$ \\
\hline 14 & c. $1235 \mathrm{C}>\mathrm{T}$ & $3 / 44(T)$ & ND & ND & p.Ala412Val & $Y$ \\
\hline 16 & c. $1501 \mathrm{G}>\mathrm{A}$ & $12 / 44(\mathrm{~A})$ & ND & ND & p.Gly501Ser & $Y$ \\
\hline 22 & c. $1927 C>G$ & $8 / 44(G)$ & ND & ND & p.Pro643Ala & $Y$ \\
\hline 26 & c. $2426 \mathrm{~A}>\mathrm{G}$ & $19 / 44(G)$ & ND & ND & p.Glu809Asp & $Y$ \\
\hline 27 & c. $2574 C>G^{*}$ & $5 / 154(G)$ & $1 / 124$ & $18 / 848$ & p.Ser858Arg & $Y$ \\
\hline 30 & c. $2901 \mathrm{C}>\mathrm{T}$ & $5 / 44(T)$ & ND & ND & None & $Y$ \\
\hline 33 & c. $3263 C>T$ & $7 / 44(T)$ & ND & $8 / 115$ & p.Ser1088Phe & $Y$ \\
\hline 37 & c. $3654 A>G$ & $7 / 44(G)$ & ND & ND & None & Y \\
\hline 38 & c. $3807 G>C$ & $5 / 44(C)$ & ND & ND & None & $Y$ \\
\hline
\end{tabular}

*FA associated variant; ffrequency is shown as the number of alleles containing the nucleotide in parentheses over the total number of alleles examined from familial pancreatic cancer samples; $\ddagger N D$, not determined; $\S Y$ indicates present and N indicates not present in the Fanconi Anemia Mutation Database at http:// www.rockefeller.edu/fanconi/mutate/jumpa.html. DNA numbering is based on the cDNA sequence. The GenBank reference sequence and version number NM_000135.1 was used. Position +1 corresponds to the A of the ATG translation initiation codon. Protein sequences are numbered with the initiator methionine as codon 1 .

cholecystectomy controls, in three of 115 spousal controls, and in 15 of 668 colonoscopy controls (table 1). We also determined that there was no loss of heterozygosity at the FANCA locus of a pancreatic cancer xenograft generated from a familial pancreatic cancer patient with a c.2574C $>$ G variant. The evidence that the c.2754C $>$ G (p.Ser858Arg)

Table 2 Intronic FANCA sequence variants in familial pancreatic cancer

\begin{tabular}{|c|c|c|c|}
\hline Intron & Nucleotide change & Frequency* & FA database $†$ \\
\hline 3 & c. $283+44 \mathrm{~T}>\mathrm{C}$ & $2 / 44(C)$ & $\mathrm{N}$ \\
\hline 3 & c. $284-103 T>C$ & $1 / 44(C)$ & $\mathrm{N}$ \\
\hline 3 & c. $284-151 C>T$ & $1 / 44(T)$ & $\mathrm{N}$ \\
\hline 4 & c. $426+68 A>G$ & $8 / 44(G)$ & $\mathrm{N}$ \\
\hline 7 & c. $710-12 A>G$ & $24 / 44(\mathrm{~A})$ & Y \\
\hline 8 & c. $792+52 C>G$ & $1 / 44(G)$ & $\mathrm{N}$ \\
\hline 8 & c. $792+81 \_82$ del & $1 / 44$ & $\mathrm{~N}$ \\
\hline 10 & c. $894-30 A>G$ & $7 / 44(G)$ & $\mathrm{N}$ \\
\hline 12 & c. $1084-93 C>T$ & $18 / 44(T)$ & $\mathrm{N}$ \\
\hline 12 & c. $1084-49 G>C$ & $19 / 44(C)$ & $Y$ \\
\hline 12 & c. $1084-29 A>G$ & $12 / 44(G)$ & Y \\
\hline 13 & c. $1226-20 A>G$ & $14 / 44(G)$ & Y \\
\hline 18 & c. $1715+82 \mathrm{~T}>\mathrm{C}$ & $16 / 44(C)$ & $Y$ \\
\hline 19 & c. $1777-29 T>C$ & $7 / 44(C)$ & $\mathrm{N}$ \\
\hline 20 & c. $1826+15 T>C$ & $9 / 44(C)$ & $Y$ \\
\hline 20 & c. $1826+30$ insGT & $7 / 44$ & Y \\
\hline 22 & c. $2014+42 \mathrm{G}>\mathrm{T}$ & $8 / 44(T)$ & $Y$ \\
\hline 22 & c. $2015-71 \mathrm{G}>\mathrm{A}$ & $2 / 44(\mathrm{~A})$ & $\mathrm{N}$ \\
\hline 25 & c. $2316+67 A>G$ & $2 / 44(G)$ & $\mathrm{N}$ \\
\hline 25 & c. $2316+96 G>T$ & $1 / 44(T)$ & $\mathrm{N}$ \\
\hline 27 & c. $2602-36 G>T$ & $1 / 44(T)$ & $Y$ \\
\hline 27 & c. $2602-46 \mathrm{~T}>\mathrm{A}$ & $1 / 44(\mathrm{~A})$ & $\mathrm{N}$ \\
\hline 28 & c. $2778+55 G>T$ & $1 / 44(\mathrm{~T})$ & $\mathrm{N}$ \\
\hline 28 & c. $2779-7 T>C$ & $5 / 44(C)$ & $\mathrm{N}$ \\
\hline 31 & c. $3066+55 A>G$ & $15 / 44(G)$ & $\mathrm{N}$ \\
\hline 31 & c. $3067-4 T>C$ & $6 / 44(C)$ & $Y$ \\
\hline 31 & c. $3067-23 G>A$ & $6 / 44(A)$ & Y \\
\hline 31 & c. $3067-57 \mathrm{~A}>\mathrm{C}$ & $6 / 44(C)$ & Y \\
\hline 32 & c. $3240-42 G>A$ & $12 / 44(\mathrm{~A})$ & $Y$ \\
\hline 34 & c. $3408+45 G>A$ & $6 / 44(\mathrm{~A})$ & $Y$ \\
\hline 35 & c. $3513+62 C>T$ & $8 / 44(T)$ & $Y$ \\
\hline 37 & c. $3765+37 A>G$ & $6 / 44(G)$ & $\mathrm{N}$ \\
\hline 38 & c. $3829-82 C>G$ & $6 / 44(G)$ & Y \\
\hline 39 & c. $3935-16 C>T$ & $6 / 44(T)$ & $Y$ \\
\hline 39 & c. $3935-102 C>T$ & $1 / 44(T)$ & $\mathrm{N}$ \\
\hline 42 & c. $4260+29 C>T$ & $24 / 44(C)$ & $Y$ \\
\hline
\end{tabular}

*Frequency is shown as the number of alleles containing the nucleotide in parentheses over the total number of alleles examined from familial pancreatic cancer samples; $\uparrow Y$ indicates present and $N$ indicates not present in the Fanconi Anemia Mutation Database at http:// www.rockefeller.edu/fanconi/mutate/jumpa.html. DNA numbering is based on the cDNA sequence. The GenBank reference sequence and version number NM_000135.1 was used. Position +1 corresponds to the A of the ATG translation initiation codon. Protein sequences are numbered with the initiator methionine as codon 1 . variant is likely to be disease causing is based on reports in the literature that it has been found in four unrelated patients with FA who, apart from inactivation of their second allele by mutation, had no other genetic explanation for their FA. ${ }^{17}$ In addition, FANCA protein harbouring the p.Ser858Arg amino acid change is unable to monoubiquitinate FANCD2. ${ }^{18}$ Thus, the FANCA p.Ser858Arg variant appears to cause FA in individuals whose other germline allele is also mutated and produces a protein lacking normal FANCA function. However, this variant is not conserved in mice, and since we did not find this variant more often in individuals with familial pancreatic cancer than in controls, our genetic epidemiological evidence indicates that the FANCA p.Ser858Arg variant does not contribute to familial pancreatic cancer.

The c.3263C $>$ T variant in exon 33, which was previously considered a mutation, ${ }^{16}$ was recently shown to be a polymorphism. ${ }^{19}$ Our results also confirm this (OR 1.19, 95\% CI 0.85 to 7.45 ) (table 1). Electropherograms corresponding to heteroduplex analysis of exons 27 and 33 are shown in fig 1 . Two novel variants of uncertain significance were identified, c.377C $>$ G (p.Thr126Arg) and c.661A $>$ G (p.Met22lVal), which were not found in 115 spousal controls. These variants are not conserved in mouse or rat (codon 126 is valine and codon 221 is an isoleucine).

One obstacle to determining the significance of variants is the paucity of surgically resected cancers from affected carriers of suspicious variants to demonstrate the presence or absence of biallelic inactivation of FANCA. Another problem is the lack of segregation data for these variants, which is the result of obstacles inherent to studying the genetics of familial pancreatic cancer. Since pancreatic cancer usually occurs in older individuals and usually displays only moderate penetrance within a family, it is difficult to track the inheritance of suspected disease causing sequence alterations with sufficient numbers of affected individuals in a family to infer disease causality. For example, of $\sim 1400$ kindred enrolled in our National Familial Pancreas Tumor Registry (as of August 2004), only 188 ( 14\%) contain three or more individuals with pancreatic cancer. Furthermore, since the interval between pancreatic cancers in these families can span decades and since pancreatic cancer is usually rapidly fatal, generally DNA is obtainable from only a small proportion of affected individuals.

Cells that lack normal FANCA function are hypersensitive to DNA damage and individuals with FA have a greatly increased risk of multiple cancers. ${ }^{20}$ Since FANCA is a DNA repair gene, cells from carriers of heterozygous mutations that underwent somatic inactivation of the remaining wildtype allele would be expected to have an increase in mutation 

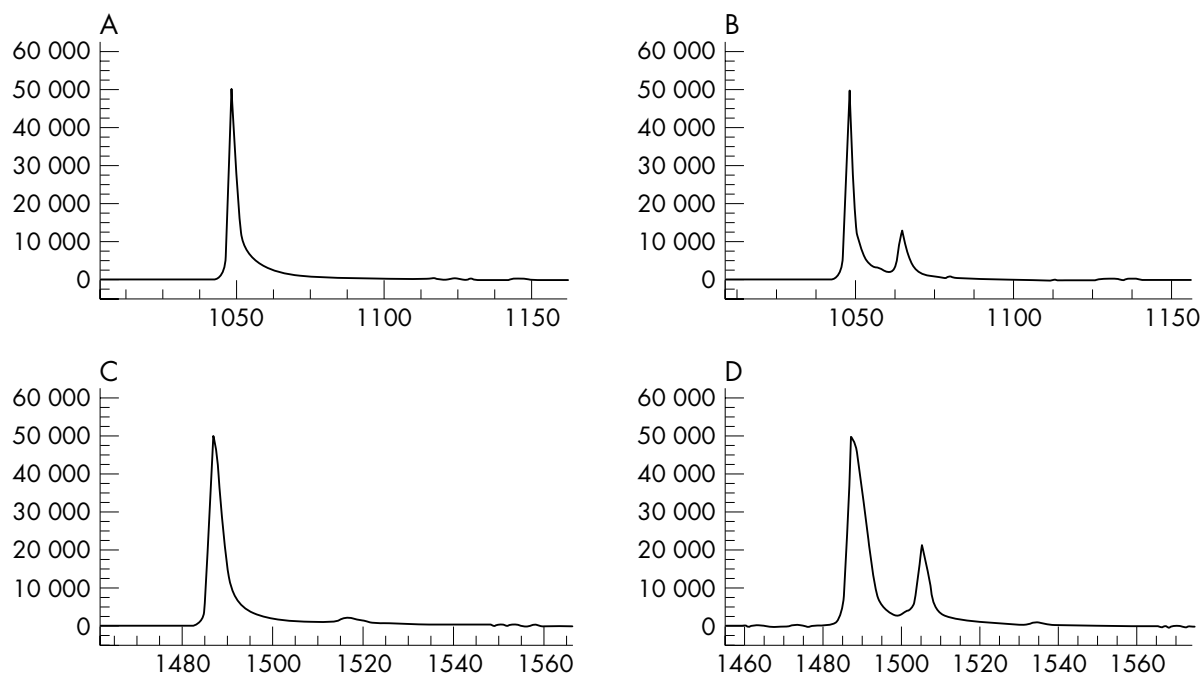

Figure 1 Heteroduplex analysis of the FANCA c. $2574 C>G$ and c. $3263 C>$ T variants. DNA fragments containing exons 27 and 33 were subjected to temperature gradient capillary gel electrophoresis. Electropherograms corresponding to heteroduplex analysis of exons 27 and 33 are shown. Panels A and B show exon 27 control and c. $2574 C>G$ variant results, respectively. Panels $C$ and D show exon 33 control and c. $3263 C>T$ variant results, respectively. The $x$ axis represents the migration of the amplicon and the $y$ axis represents the relative fluorescence units.

rate and increased likelihood of cancer development. However, it has been difficult to demonstrate that heterozygote carriers of most FANC gene mutations have an increased risk of developing cancer, ${ }^{21}{ }^{22}$ with the exception of BRCA2. Although pancreatic cancer is not one of the cancers that commonly occur in patients with FA, this could arise from the greater risk of developing other cancers. In addition, the occurrence of cancers in affected individuals may also be highly dependent on environmental exposures. ${ }^{23}$ However, the results of this study, our previous study of FANCC and FANCG in familial pancreatic cancer, and the lack of germline mutations in Fanconi genes in familial breast cancers families ${ }^{19}$ suggest that any contribution of heterozygote germline FANC gene mutations to cancer predisposition is likely to be a modest one. ${ }^{19}$

Recent work (Kern and coworkers) confirms that pancreatic cancer cells with inactivation of Fanconi genes are hypersensitive to mitomycin C. ${ }^{24}{ }^{25}$ Given the lack of useful chemotherapeutics for pancreatic cancer, it is imperative that methods are developed to identify cancers with inactivation of the Fanconi pathway. This sensitivity to mitomycin C may also extend to cancers with inactivation of BRCA2 (FANCD1) as well as to those with FANCF inactivation due to epigenetic silencing by DNA methylation..$^{26-28}$

\section{ACKNOWLEDGEMENTS}

We thank the SpectruMedix Corporation, State College, PA for use of their SCE 9610 sequencer for TGCE analysis.

\section{ELECTRONIC-DATABASE INFORMATION}

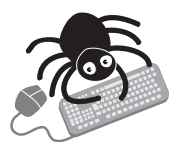

A detailed description of methods used can be accessed at http://www. pathology2.jhu.edu/ pancreas/FANCA and at http://jimg.bmijournals. com/supplemental/. The Fanconi Anemia Mutation Database can be found at http://www.rockefeller. edu/fanconi/mutate/jumpa.html.

\footnotetext{
Authors' affiliations

C D Rogers, K Brune, S T Martin, J Philips, K M Murphy, R H Hruban, M Goggins, Department of Pathology, The Johns Hopkins Medical Institutions, Baltimore, MD 21205-2196, USA
}

C J Yeo, R H Hruban, M Goggins, Department of Oncology, The Johns Hopkins Medical Institutions, Baltimore, MD 21205-2196, USA

F J Couch, Department of Laboratory Medicine and Pathology, Mayo Clinic College of Medicine, 200 First Street Southwest, Rochester, MN 55905, USA

G Petersen, Health Sciences Research, Mayo Clinic College of Medicine, 200 First Street Southwest, Rochester, MN 55905, USA

C J Yeo, Department of Surgery, The Johns Hopkins Medical Institutions, Baltimore, MD 21205-2196, USA

M Goggins, Department of Medicine, The Johns Hopkins Medical Institutions, Baltimore, MD 21205-2196, USA

This study was supported by a SPORE in Gastrointestinal Cancer grant (CA62924) and a SPORE in Pancreatic Cancer (CA102701) grant. CR is supported by a minority fellowship award from the $\mathrm{NCl}$.

Conflict of interest: none declared.

Correspondence to: Dr Michael Goggins, Johns Hopkins School of Medicine, 720 Rutland Avenue, 632 Ross Building, Baltimore, MD 21205, USA; mgoggins@ihmi.edu

Revised version received 20 August 2004

Accepted for publication 23 August 2004

\section{REFERENCES}

1 Howlett NG, Taniguchi T, Olson S, Cox B, Waisfisz Q, De Die-Smulders C, Persky N, Grompe M, Joenje H, Pals G, Ikeda H, Fox EA, D'Andrea AD. Biallelic inactivation of BRCA2 in Fanconi anemia. Science 2002;297(5581):606-9.

2 Van Der Heijden MS, Yeo CJ, Hruban RH, Kern SE. Fanconi anemia gene mutations in young-onset pancreatic cancer. Cancer Res 2003;63(10):2585-8

3 Rogers C, van der Heijden M, Brune K, Yeo C, Hruban R, Kern S, Goggins M. The genetics of FANCC and FANCG in familial pancreatic cancer. Cancer Biol Ther 2004;3(2):167-9.

4 Levitus M, Rooimans MA, Steltenpool J, Cool NF, Oostra AB, Mathew CG, Hoatlin ME, Waisfisz Q, Arwert F, De Winter JP, Joenje H, Tischkowitz M, Ameziane N, Harris R, Taniguchi T, D'Andrea A, Hodgson SV. Heterogeneity in Fanconi anemia: evidence for two new genetic subtypes: bi-allelic silencing of the Fanconi anaemia gene FANCF in acute myeloid leukaemia. Blood 2003;20(3):20

5 Joenje $H$, Oostra AB, Wijker M, di Summa FM, van Berkel CG, Rooimans MA, Ebell W, van Weel M, Pronk JC, Buchwald M, Arwert F. Evidence for at least eight Fanconi anemia genes. Am J Hum Genet 1997;61(4):940-4.

6 Joenje H, Levitus M, Waisfisz Q, D'Andrea A, Garcia-Higuera I, Pearson T, van Berkel CG, Rooimans MA, Morgan N, Mathew CG, Arwert F. Complementation analysis in Fanconi anemia: assignment of the reference FAH patient to group A. Am J Hum Genet 2000;67(3):759-62.

7 Meetei AR, de Winter JP, Medhurst AL, Wallisch M, Waisfisz Q, van de Vrugt HJ, Oostra AB, Yan Z, Ling C, Bishop CE, Hoatlin ME, Joenje H, 
Wang W. A novel ubiquitin ligase is deficient in Fanconi anemia. Nat Genet 2003;35(2): 165-70

8 Strathdee CA, Gavish H, Shannon WR, Buchwald M. Cloning of cDNAs for Fanconi's anaemia by functional complementation. Nature 1992; 358(6385):434.

9 Lo Ten Foe JR, Rooimans MA, Bosnoyan-Collins L, Alon N, Wijker M, Parker L, Lightfoot J, Carreau M, Callen DF, Savoia A, Cheng NC, van Berkel CG, Strunk MH, Gille JJ, Pals G, Kruyt FA, Pronk JC, Arwert F, Buchwald M, Joenje $\mathrm{H}$. Expression cloning of a cDNA for the major Fanconi anaemia gene, FAA. Nat Genet 1996;14(3):320-3.

10 de Winter JP, Rooimans MA, van Der Weel L, van Berkel CG, Alon N Bosnoyan-Collins L, de Groot J, Zhi Y, Waisfisz Q, Pronk JC, Arwert F, Mathew CG, Scheper RJ, Hoatlin ME, Buchwald M, Joenje H. The Fanconi anaemia gene FANCF encodes a novel protein with homology to ROM. Nat Genet 2000;24(1):15-6.

11 de Winter JP, Waisfisz Q, Rooimans MA, van Berkel CG, Bosnoyan-Collins L, Alon N, Carreau M, Bender O, Demuth I, Schindler D, Pronk JC, Arwert F, Hoehn $H$, Digweed $M$, Buchwald $M$, Joenje $H$. The Fanconi anaemia group $G$ gene FANCG is identical with XRCC9. Nat Genet 1998;20(3):281-3.

12 Hejna JA, Timmers CD, Reifsteck C, Bruun DA, Lucas LW, Jakobs PM, TothFejel S, Unsworth N, Clemens SL, Garcia DK, Naylor SL, Thayer MJ, Olson SB Grompe M, Moses RE. Localization of the Fanconi anemia complementation group D gene to a 200-kb region on chromosome 3p25.3. Am J Hum Genet 2000;66(5): 1540-51

13 Whitney M, Thayer M, Reifsteck C, Olson S, Smith L, Jakobs PM, Leach R, Naylor S, Joenje H, Grompe M. Microcell mediated chromosome transfer maps the Fanconi anaemia group D gene to chromosome 3p. Nat Genet $1995 ; 11(3): 341-3$.

14 Tischkowitz MD, Hodgson SV. Fanconi anaemia. J Med Genet 2003;40(1):1-10

15 Goggins M, Schutte M, Lu J, Moskaluk CA, Weinstein CL, Petersen GM, Yeo CJ, Jackson CE, Lynch HT, Hruban RH, Kern SE. Germline BRCA2 gene mutations in patients with apparently sporadic pancreatic carcinomas. Cancer Res 1996;56(23):5360-4

16 Wijker M, Morgan NV, Herterich S, van Berkel CG, Tipping AJ, Gross HJ, Gille JJ, Pals G, Savino M, Altay C, Mohan S, Dokal I, Cavenagh J, Marsh J, van Weel M, Ortega JJ, Schuler D, Samochatova E, Karwacki M, Bekassy AN, Abecasis M, Ebell W, Kwee ML, de Ravel T, Mathew CG, et al. Heterogeneous spectrum of mutations in the Fanconi anaemia group A gene. Eur J Hum Genet 1999;7(1):52-9.

17 Tamary H, Bar-Yam R, Shalmon L, Rachavi G, Krostichevsky M, Elhasid R, Barak Y, Kapelushnik J, Yaniv I, Auerbach AD, Zaizov R. Fanconi anaemia group A (FANCA) mutations in Israeli non-Ashkenazi Jewish patients. Br J Haematol 2000;111(1):338-43.

18 Savino M, Borriello A, D'Apolito M, Criscuolo M, Del Vecchio M, Bianco AM, Di Perna M, Calzone R, Nobili B, Zatterale A, Zelante L, Joenje H, Della Ragione F, Savoia A. Spectrum of FANCA mutations in Italian Fanconi anemia patients: identification of six novel alleles and phenotypic characterization of the S858R variant. Hum Mutat 2003;22(4):338-9.

19 Seal S, Barfoot R, Jayatilake H, Smith P, Renwick A, Bascombe L, McGuffog L, Evans DG, Eccles D, Easton DF, Stratton MR, Rahman N. Evaluation of Fanconi anemia genes in familial breast cancer predisposition. Cancer Res 2003:63(24):8596-9.

20 Alter BP. Cancer in Fanconi anemia, 1927-2001. Cancer 2003;97(2):425-40

21 Potter NU, Sarmousakis C, Li FP. Cancer in relatives of patients with aplastic anemia. Cancer Genet Cytogenet 1983:9(1):61-5.

22 Swift M, Caldwell RJ, Chase C. Reassessment of cancer predisposition of Fanconi anemia heterozygotes. J Natl Cancer Inst 1980;65(5):863-7.

23 Boffetta P, Nyberg F. Contribution of environmental factors to cancer risk. $\mathrm{Br}$ Med Bull 2003;68:71-94.

24 Van Der Heijden MS, Brody JR, Kern SE. Functional screen of the Fanconi anemia pathway in cancer cell by Fancd2 immunoblot. Cancer Biol Ther 2004;3:6.

25 Van der Heijden MS, Brody JR, Gallmeier E, Cunningham SC, Dezentje DA, Shen D, Hruban RH, Kern SE. Functional defects in the Fanconi anemia pathway in pancreatic cancer cells. Am J Pathol 2004; 165(2):651-7.

26 Tischkowitz M, Ameziane N, Waisfisz Q, De Winter JP, Harris R, Taniguchi T, D'Andrea A, Hodgson SV, Mathew CG, Joenje H. Bi-allelic silencing of the Fanconi anaemia gene FANCF in acute myeloid leukaemia. $\mathrm{Br} J \mathrm{Haemato}$ 2003;123(3):469-71.

27 Taniguchi T, Tischkowitz M, Ameziane N, Hodgson SV, Mathew CG Joenje H, Mok SC, D'Andrea AD. Disruption of the Fanconi anemia-BRCA pathway in cisplatin-sensitive ovarian tumors. Nat Med 2003;9(5):568-74

28 Marsit CJ, Liu M, Nelson HH, Posner M, Suzuki M, Kelsey KT. Inactivation of the Fanconi anemia/BRCA pathway in lung and oral cancers: implications for treatment and survival. Oncogene 2004;23(4):1000-4. 